DOI: 10.22559/folklor.1063

folklor/edebiyat, cilt: 25 , sayı: 100, 2019/4

\title{
Türkiye'de Yapılan Popüler Dede Korkut Kitabı Yayınları
}

\section{Popular Editions of the Book of Dede Korkut in Turkey}

\section{Metin Özarslan* Ergün Veren ${ }^{* *}$}

Öz

On iki boydan meydana gelen Dede Korkut Kitabı Orta Asya'dan batıya göçen Oğuzların XI. yüzyıl başlarındaki hayatlarını anlatan destanî hikâyelerin toplandığı bir yazılı kaynaktır. Söz konusu destanî hikâyeler Oğuz bölgesindeki Türk Boyları arasında İslam dini ile tanışmalarını takip eden yüzyıllar içinde sözlü kültür ortamında oluşmuş ve muhtemelen XV. yüzyıl sonlarıyla XVI. yüzyıl başlarında yazılı kültür ortamına aktarılmışlardır. Bu kitap Türk kültürünün çeşitli alanlarına ilişkin bilgileri içerdiği için temel yazılı kaynaklarından biri olarak kabul edilmektedir. Dede Korkut boyları irdelendiklerinde Türk kültürel belleğinin kimi saklı değerlerini içerdikleri görülmektedir. Dede Korkut Kitabı üzerine Türkiye'de 1916-2015 yılları arasında tez, makale, kitap ve sanatsal formlu bilimsel, popüler ve sanatsal 1638'den fazla yayın yapılmıştır. Bu çalışmada yüz yıllık süreçte Dede Korkut Kitabı'nın Türkiye'deki popüler yayınlarının üretim ve yayım işleyişi ele alınmıştır. Örnekleme yöntemiyle se-

* Prof. Dr., Hacettepe Üniversitesi Edebiyat Fakültesi Türk Halkbilimi Bölümü. metino@hacettepe.edu.tr

*** MA., Türk Halkbilimi Uzmanı, ergunveren@hotmail.com 
çilen 456 popüler yayının künye bilgileri üzerinden "kitap-yazar-dönem-okur hedef kitle" ana ölçütleriyle, nicelik/nitelik merkezinde analizleri yapılarak, yayınların üretiminde ve yayımında bu unsurların etkileri etüt edilmiştir. $\mathrm{Bu}$ çalışmanın araştırma alanını Millî Kütüphane katalogları ile Türkiye'de yayımlanmış kimi biyografik yayınlardan oluşmuştur. Disiplinler arası yaklaŞımla ele alınan çalışmada, istatistik alanının ölçme düzeyleri (ölçekler) ve istatiksel seri yöntemleri kullanılmıştır. Sonuçta Türkiye'de yayımlanan popüler Dede Korkut Kitabı yayınlarında genelde hangi sebep ve saiklerin etkili olduğu tespit ve tayin edilmiştir.

Anahtar sözcükler: Dede Korkut Kitabı, destan, boy, hikâye, popüler kitap, Türkiye

\begin{abstract}
The Book of Dede Qorqut is a collection of twelve stories set in the heroic age of the Oghuz Turks. A nomadic tribe who had journeyed westwards through Central Asia from the ninth century onwards. This book is accepted as one of the basic written sources because it contains information on various fields of Turkish culture. It is seen that it contains some hidden values of Turkish cultural memory, when Dede Qorqut were examined. In Turkey, between 19162015 more than 1638 scientific, popular and artistic Works including theses, articles and books on the Book of Dede Qorqut were published. In this work, the production and publishing process of the popular publications of The Book of Dede Qorqut was studied within a period of a 100 years. Based on the imprint information of 456 popular publications were chosen with the exemplification method, main criterion of "book-writer-reader-target audience", analyzing them in terms of quality and quantity, the effects of these elements on the production and the publication of the works were studied. The research of this work, consists of The National Library catalogs and some biographical publications published in Turkey. It was studied with an interdisciplinary approach, and quantification levels (scales) of statistics and the methods of statistical data were used. As a result, the reasons and motives of which were effective in popular publications on The Book of Dede Qorqut was published in Turkey and determined and indicated.
\end{abstract}

Keywords: The Book of Dede Korkut, epik, epos, narrative, popular books, Turkey 


\section{Giriş}

Dresden ve Vatikan'da olmak üzere, bilinen iki yazma nüshası bulunan Dede Korkut Kita$b l$, destanî anlatıların [boyların] toplandığı bir eserdir. Korkut (Dede Korkut, Dedem Korkut, Korkut Ata) isimli Türk Ozan'ın “düzdüğü” bilinen boyları içeren ve Türk kültürünün temel yazılı kaynaklarından kabul edilen Dede Korkut Kitabı üzerine Türkiye'de 1916-2015 arasinda bilimsel/popüler zeminde 1638'den fazla tez, makale, kitap ve sanatsal formlu (Bekki, 2014) çalışma yayımlanmıştır. Ancak Dede Korkut Kitabı'na istatistikî olarak bakılmamış ve böyle bir değerlendirme yapılmamıştır.

Bu çalışmada yüz yıllık süreçte Dede Korkut Kitabı'nın Türkiye'deki popüler yayınlarının üretim ve yayım işleyişi istatistikî ve metinlerarası zeminde ele alınmıştır. Türkiye'de 1916 yılından başlayarak yapılan popüler yayınların' gerçekleştirilme nedenleri "kitapyazar-dönem-okur hedef kitle" ölçütlerine bağlı olarak, nicelik, nitelik odaklı analize tabi tutulmuştur. Örnekleme yöntemiyle ${ }^{2}$ seçilen 456 popüler yayının künye bilgileri üzerinden "kitap-yazar-dönem-okur hedef kitle" ana ölçütleriyle, nicelik/nitelik merkezinde analizleri yapılarak, yayınların üretiminde ve yayımında bu unsurların etkileri etüt edilmişstir. Bu çalışmanın araştırma alanını Millî Kütüphane katalogları ile Türkiye'de yayımlanmış kimi biyografik yayınlardan oluşmuştur. İstatistik biliminin ölçme düzeyleri ${ }^{3}$ ve istatiksel seri yöntemlerinin kullanıldığı çalışma Dede Korkut Kitabı ölçekli popüler yayınlar ${ }^{4}$ ile sınırlandırılmıştır.

\section{Dede Korkut Kitabı'nın popüler yayınlarına istatiksel bakış ve değerlendirme}

Arkaik zamanlardan başlayarak sözlü kültür ortamında oluşan anlatılar, zamanla kuşaklar arasında katmanlaşarak yazılı kültür ortamına aktarılmışlardır. Dede Korkut boyları için de bu dönüşüm süreci gerçekleşmiştir. Boylar Oğuz sahasındaki Türk Boyları arasında İslam dini ile tanışmalarını takip eden yüzyıllar içinde sözlü kültür ortamında oluşmuş; ileti, gönderici, alıcı, kanal ve geri bildirim ögelerini içeren iletişim sistematiğinde ve zaman içinde kuşaklar arasında katmanlaşarak XV-XVI. yüzyılda yazılı ortama aktarılmışlardır. Böylelikle destanî Dede Korkut boyları da metne; dinleyicileri okur'a ve anlatıcıları da yazar'a, müstensih'e dönüşmüş; kapanarak ${ }^{5}$ sesten, görsel mekâna geçmişlerdir (bkz. Ong, 1995: 140-146). Ancak, Dede Korkut Kitabı bağlamında “yazar” teriminden, Dede Korkut Kitabı'nı ya tıpkı yayımlayan ya da bilimsel, popüler veya sanatsal formlu metin biçiminde hazırlayan kişi, müstensih, anlaşılmalıdır. Yüz yıllık süreçte Dede Korkut Kitabı'nın Türkiye'deki popüler yayınlarının üretim ve yayım işleyişi, bu çalışmada iki aşamada ele alınmıştır. İlk aşamada 456 popüler yayının künye bilgileri, "yazar-yayın-okur hedef kitle" ana ölçütleriyle oluşturulan tabloda (bkz. Veren, 2018: 56-57 ve 145-185) listelenmiştir ${ }^{6}$. İkinci aşamada değişkenlerin ölçümleri, oransal ölçme düzeyinde gerçekleştirilerek üretim ve işleyiş süreci analiz edilmiştir.

\subsection{Yazar odaklı çıkarımlar ve değerlendirme}

Tablo değişkenleri yazar odaklı ölçümlendiğinde 456 adet popüler yayından (416) kitapta yazar adının kaydedildiği, (40) kitapta yazar adına yer verilmediği görülmüştür. Yayınların \%9'unda yazar adına yer verilmeyişi, yazar olarak kaydedilen isimleri gerçek veya müstear olup olmadığı gibi sorular başka çalışmanın konusu olmakla birlikte bu hususa dair aşağıdaki tespitler yapılabilir. 
Yazarın adının yayına kaydedilmemesi veya müstear ad kullanması, "sahiplenmeme isteği"nin dişa vurumu olarak değerlendirebilir. Sahiplenmeme isteğini oluşturan sebepler "sosyal, ekonomik ve hukuki sebepler" şeklinde tasnif edilebilir.

a. Sosyal sebepler: Yazarın alan hâkimiyetini koruma ve kamuoyunun vereceği olumsuz tepkilerden korunma gerekçesiyle, adını kaydetmekten kaçınması veya müstear ad kullanmasıdır. Uzmanlık alanı dışındaki ürünü yayımlayan kişinin karşılaşabileceği iki sorun vardır. Biri, uzmanlık alanı dışında da çalışma yayımlamasıyla kamuoyunda, alanındaki otoritesinden yahut popülaritesinden ödün verdiği algısının oluşması endişesidir. Diğeri ise, yayımladığg yayına kamuoyundan gelecek olumsuz tepkileri karşılamama yahut risk almama tarzı özsavunmadır.

b. Ekonomik sebepler: Yayının kamuoyunda yeterli ilgiyi görmemesi, beklenen maddi gelirin elde edilememesi veya aksine yüksek bir ilgiye ulaşması, beklenenin üzerinde maddi gelirin elde edilmesinin rakipleri nezdinde yaratacağı kıskançlık, sevinç, üzüntü vb. hâl ile maddi, manevi zarar şeklindeki sosyo-psikolojik temelli ticari kaygılardır.

c. Hukuki sebepler: Kamu görevinde veya telif hakları ihlalinde gizlenmeye yönelik kaçınma girişimleridir. Kamu görevlisi kimi yazarlar iş/meslek grubu içerisinde cezalandırılma ve mobbing (bezdirme) türü yaptırımlarla karşılaşma, etkilenme kaygısı yaşayabilmektedirler. Telif hakları ihlalinde gizlenmeye dayalı kaçınma ise aşırarak -gizli alıntı- ürettikleri yayımları yayınlayan kişiler tarafından başvurulabilecek bir davranıştır. ${ }^{7}$

\subsection{Yayın odaklı çıkarımlar ve değerlendirme}

Tablo değişkenleri yayın odaklı (yayın tarihi -dönemi-, yeri, yayıncısı, sayfa sayısı ve türü) ölçümlendiğinde aşağıdaki hususlar dikkat çekmektedir:

a. Yayın tarihlerine (dönemi) göre 456 adet popüler yayından, 1916-1925 arasında (1); 1925-1935 arasinda (11); 1936-1945 arasinda (7); 1946-1955 arasinda (5); 1956-1965 arasinda (15); 1966-1975 arasinda (29); 1976-1985 arasında (46); 1986-1995 arasinda (35); 1996-2005 arasında (113) ve 2006-2015 arasında (194) adet yayımlandığı görülmüştür. 2006-2015 arasındaki \% 43'lük oranda yayın ile (194) ilk sırada yer aldığı dönemi, \% 25'lik oranla (113) 1996-2006 arası dönemi takip etmiştir. 3. sırayı \% 10'luk oranla (46) 19761985 arası dönem alırken; \% 8'lik oranla (35) 1986-1995 arası dönem 4. sırada; \% 6'lık oranla (29) 1966-1975 arası dönem 5. sırada; \% 3'lük oranla (15) 1956-1965 arası dönem 6. sırada; \% 2'lik oranla (11) 1926-1935 arası dönem 7. sırada; \% 2'lik oranla (7) 1936-1945 arası dönem 8. sırada; \% 1'lik oranla (5) 1946-1955 arası dönem 9. sirada ve 1916-1925 arası dönem (1) son sırada yer aldığı görülmüştür. Genelde ilk dönemden başlayarak yayınlarda kademeli artış gözlemlenirken; 1926-1935 arasındaki yayın artışının bir sonraki dönemde düştüğü; 1966-1975 arasındaki yayınların önceki dönemlerin iki katına çıktığı; 1996-2005 arası ve sonrası dönemde de yayınların geçmiş dönemlere oranlara pek çok arttığı; son iki dönemdeki yayınların diğer yılların toplam yayınlarını da aşarak toplam yayınların dörtte üçüne ulaştığ dikkati çekmiştir.

b. Yayın yerlerine göre 456 adet popüler yayının ağırlıkla İstanbul (365) ve Ankara'da (68) yayımlanmasına karşın İzmir (4), Konya (4), Eskişehir (3), Trabzon (3), Bursa (1), Is- 
parta (1), Sakarya (1), Samsun (1) ve Sivas'ta (1) yayımların gerçekleştirildiği; (4) adet yayında ise yayımın yapıldığı şehrin kitaplara kaydedilmediği görülmüştür. Toplam yayınların \% 80'lik oranının, Türkiye yayın sektörünün merkezi İstanbul'da yayımlandığı; \% 15'lik oranla Ankara'da gerçekleştirilen yayımların ikinci sırada olduğu anlaşılmıştır. Yayım gerçekleştirmede Başkent'in ikinci sırada olması, şehirdeki devlet kurumları ile kamu kurum/ kuruluşlarının geçmişte kitap yayınını yoğun olarak desteklemelerinin yanı sıra son yıllarda açılan yayınevlerinin yayım faaliyetlerini arttırarak sürdürmelerinden de kaynaklanmış olabileceği kanaatine varılmıştır. Yayın miktarları İstanbul ve Ankara'da gerçekleştirilen yayımlara oranla sembolik miktarlarda olmasına karşın Bursa, Eskişehir, Isparta, İzmir, Konya, Trabzon, Sakarya, Samsun, Sivas’ta da yayım gerçekleştirilmesi, bu şehirlerdeki girişimci ve yayıncı potansiyelinin varlığı şeklinde değerlendirilmiştir.

c. Yayıncı yapısına göre 456 adet popüler yayının, \% 92'sinin özel sektör (419) ve \% 8 'inin kamu, devlet kurum/kuruluşları (27) tarafından yayımlandığı görülmüştür. Kamu/devlet kurum ve kuruluşlarının yayım gerçekleştirme oranının düşmesi, sınırlı bütçeye sahip olmalarının yanı sıra Avrupa Birliği uyum yasaları çerçevesinde devlet kurumlarının yayıncılıktan büyük oranda el çekmesiyle ilişkilendirilmiştir.

d. Yayınların sayfa sayılarına göre 456 adet popüler yayından 100-200 sayfa (142), 0-50 sayfa (120), 200+ sayfa (100) ve 50-100 sayfalardan (94) oluşan kitaplar olduğu görülmüştür. Yayınların sayfa sayılarına göre aralarında oransal farkın çok olmadığı anlaşılmıştır. Yayınların sayfa sayılarının belirlenmesinde sayfa düzeni, okur hedef kitlenin veya yazarın tercihleri, ticari kaygılar vb. pek çok neden etkili olabilmektedir. Bu çalışmada irdelenen yayınlarda da benzer nedenlerin etkili olduğu değerlendirilmiştir.

e. Yayınların türüne göre 456 adet popüler yayının hikâye (265), boy (130), roman (25), masal (22) ve senaryo (14) nitelendirmesiyle yayımlandıkları görülmüştür. \% 58'lik oranla hikâye türünün ilk sırayı aldığı yayınlarda; ikinci sırada \% 29'luk oranla boy; üçüncü sırada $\%$ 5'lik oranla roman; dördüncü sırada \% 5'lik oranla masal ve son sırada da \% 3'lük oranla senaryo türünün yer aldığı göze çarpmıştır. Yazar veya yayıncıların, kimi yayımlarında yayın türlerinin kategorisini -hikâye, masal, senaryo vb.- belirtmezken kimi yayımlarının kategorisini de edebiyat bilimi kavramlarından öte, okur hedef kitlesini dikkate alarak belirledikleri anlaşılmıştır (bkz. Güvenç, 2014: 95-412). Bu durumda yayınların, kapsamına girdiği edebiyat kategorisinin tespiti okura ${ }^{8}$ düşmektedir. Analizi yapılan yayınlar incelendiğinde yayın türü boy olarak nitelendirilen yayınların, Orhan Şaik Gökyay ve Muharrem Ergin'in Dresden Nüshası'ndan güncel Türkçe'ye aktardığı Dede Korkut Kitabı'nın yayım tekrarları olduğu dikkati çekmiştir. Diğer yandan roman (\% 5) ve senaryo (\% 3) türü yayınların varlığı, Dede Korkut Kitabı'nın sanatsal formlu ürünlerinin de ortaya konulduğunu göstermiştir.

\subsection{Okur-hedef kitle odaklı çıarımlar ve değerlendirme}

Tablo değişkenleri okur-hedef kitle odaklı ölçümlendiğinde, 456 adet popüler yayının çocuk okur hedef kitleye (274) ve yetişkin okur-hedef kitleye (182) yönelik yayımlandığ1 görülmüştür. Çocuk kavramı bağlamlarına göre farklılıklar göstermektedir. Psikolojide oral dönem (bebeklik dönemi 0-2 yaş), ilk çocukluk dönemi (2-6 yaş), orta çocukluk dönemi (okul çağı 6-12 yaş), ergenlik dönemi (12-18 yaş) şeklinde sınıflandırılmıştır (Akyüz, 2012: 
89-97). Yayıncılıkta da genellikle bu sınıflandırmanın kabul edildiği görülmüştür. Dede Korkut Kitabı'nın popüler yayınlarında da orta çocukluk (okul çağı 6-12 yaş) döneminin "çocuk okur hedef kitle"; ergenlik dönemi ve üstünün de "yetişkin okur hedef kitle" olarak hedeflendiği anlaşılmıştır. Ayrıca yayınların \% 60'lık oranının çocuk okur hedef kitleye yönelik olması da dikkat çekicidir. Çocuk okur hedef kitleye yönelik "tek boy" biçiminde yapılan yayınların "Deli Dumrul” (34 adet); "Boğaç/ Han” (25); "Tepegöz” (21); "Bamsı Beyrek” (14); "Kan Turalı" (11); "Salur Kazan/ Salur Kazan'ın Tutsaklığı" (8); "Yiğenek" (7); "Emren" (5); “Segrek” (4); "Beyrek'in Ölümü” (3); "Uruz Tutsak” (3); "Banu Çiçek” (2); "Selcan Hatun” (2); "Kazan Bey Oğlu Uruz" (1); "Burla" (1) ve "Basat” (1) başlıklarıyla yayımlandığı tespit edilmiştir.

\section{Popüler yayınların dönemsel analiz denemesi}

Dede Korkut Kitabı zemininde hazırlanan yayınlar, yayımlandığı dönem konjonktüründen etkilenmişler midir? Konjonktür, yayınlara nitelik ve nicelik bağlamında nasıl bir etki yapmıştır? Dönemsel analiz denemesiyle bu soruların cevaplarına ulaşılabilir. Bu amaçla 1916-2015 yılları arası dönem, onar yıllık alt dönem gruplarına ayrılarak irdelenmiştir.

\subsection{6-1925 yılları arası dönem}

1916-1925 yılları arası, geç Osmanlı dönemi ve erken Cumhuriyet dönemini kapsaması nedeniyle geçiş süreci özelliği taşıyan dönemdir. Birinci Dünya Savaşı ve sonrasında Osman11 Devletinin toprak kayıpları ve işgallerle karşı karşıya kalması, Anadolu'da Mustafa Kemal Atatürk önderliğinde işgallere karşı Millî direnişsin başlaması, Türkiye Büyük Millet Meclisinin açılışı, ulusal kurtuluş savaşının gerçekleştirilmesi, saltanatın kaldırılması ve Türkiye Cumhuriyetinin ilan edilmesi bu dönemin siyasî gelişmeleridir.

İşgal, savaş ve inşa sürecinin yaşandığı bu dönem eğitim ve kültür alanındaki faaliyetler olabildiğince gerçekleştirilmeye çalışılmıştır. Dede Korkut Kitabı'nın Berlin'de bulunan (Pertsch, Türkçe yazmalar kataloğu, Nu.: 203, s. 227 vd.) nüshası, kataloglarda Âsâr-1 İslâmiye ve Milliye Tedkik Encümeni reisi Ali Emîrî Efendi'nin dikkatini çekmiş ve Maarif Nezareti aracılığı ile İstanbul'a getirtmiş; Kilisli Muallim Rifat [Bilge] tarafından da 1916 yılında İstanbul'da Matbaa-i Âmire'de bastırılmıştır (Gökyay, 1938: I).

Türkiye Büyük Millet Meclisinin açılışını takiben kurulan ilk hükümetin 09.05.1920 tarihinde okunan “İcra Vekilleri Heyeti Programı”nda eğitim-öğretim konuları bölümde ders kitaplarıyla edebi ve sosyal kitapların bilgili ve yetenekli kişilere yeniden yazdırılması kaydedilmiştir. 1922 yılında Kazım Karabekir tarafından halk kitaplarının düzeltilip iyileştirilmesi gerektiği görüşü ileri sürülmüş ve bu görüş dönemin Maarif Vekâletine bildirilmiştir. 1923 yılında Maarif Vekâleti tarafından Misak-1 Maarif olarak bilinen "Umumi Maarif ve Terbiye Programı"nda yeniden bastırılan kitapların ücretsiz olarak halka dağıtılması ve zorla okutulması uygulamalarına yer verilmiştir. 1924 yılında "Tevhid-i Tedrisat Kanunu” kabul edilerek eğitim-öğretim kurumları devlet bünyesinde toplanmıştır (Binbaşığlu 2005: 241, Güvenç 2014: 47-50, Karabekir 2008: 1178). Dede Korkut Kitabı'nın popüler yayınları bağlamında bu dönemde Kilisli Muallim Rifat'ın çalışmasının ardından Ziya Gökalp tarafından, Yeni 
Mecmua'nın Ağustos 1917 ayı nüshalarında "Dede Korkut Masallarından: Deli Dumrul" (Ziya Gökalp, 1917a); "Dede Korkut Masallarından: Tepegöz" (1917b); "Dede Korkut Masallarından: Boğa ve Boğaç” (1917c) başlıklarıyla yayımlanan kimi boylardan başka 1923 yılında Altun Işık kitabında "Deli Dumrul” ve "Arslan Basat" (1923) boyları Arap harfli Türk alfabesiyle yayımlanmıştır (Güvenç, 2014: 299, 429-430).

\subsection{6-1935 yılları arası dönem}

1926-1935 y1lları arası, erken Cumhuriyet döneminin, yeniden yapılanma sürecinin devam ettiği dönemdir. Yeni Türk Harflerinin Kabulü ve Tatbiki Hakkında Kanunun kabulü; Türk Tarih Kurumu ve Türk Dil Kurumunun kuruluşu; Matbuat Kanunu'nun yürürlüğe girişi; Maarif Vekâleti bünyesinde Talim ve Terbiye Dairesinin kuruluşu; 1930 yılından itibaren halk okuma odalarının açılmaya başlaması; 1932 yılında Halkevlerinin açılması ve Matbuat ve Neşriyat Umum Müdürlüğünün daha geniş bir yapılanmaya gidişi, bu dönemin eğitim ve kültür alanındaki önemli gelişmeleridir.

Dede Korkut Kitabı'nın popüler yayınları bağlamında bu dönemde Mustafa Rahmi'nin 1927 yılında Arap harfli Türk alfabesi ile yayımladığı Korkut Ata'nın Kitabı: Evvel Zamanda $^{9}$ kitabından başka yeni Türk harfleri ile 1929 yılında, Tahsin Demiray'ın (2) adet masal ve hikâye; 1933 yılında, İffet Halim Oruz'un piyes senaryosu; 1935 yılında, Hüseyin Namık Orkun'un da yetişkin okur hedef kitle için boy, çocuk okur hedef kitle için (5) adet masal, Şerif Ferruh Gürol'un hikâye kitabının yayımlandığı görülmüştür. Yayımlanan (11) adet yayının yazarları kayıtlı olup; bunların İstanbul (3) ve Ankara'da (7) yayımlandığı; bu yayımların özel sektör (8) ve devlet kurumları (3) yayını olduğu; çoğunluğu 0-50 sayfa aralığında ve hikâye ağırlıklı yayın oldukları anlaşılmıştır. 1935 yılında Dede Korkut Kitabı odaklı piyes senaryosu yayımlanmasını önemli bir gelişme olarak görmek gerekmektedir. Ancak, Türkiye Cumhuriyeti devletinin inşa döneminde yürürlüğe koyduğu kararların tatbiki, Ankara' da yayıncılık alanındaki girişimciliğin ağırlığını hissettirmesi ve Türk kültürel belleğinin canlandırılmasına yönelik bu önemli gelişmelerin sonraki iki dönemde yavaşladığı dikkatlerden kaçmamıştır.

\subsection{6-1945 yılları arası dönem}

1936-1945 y1lları arası, dünya ve Türkiye için İkinci Dünya savaşı ve öncesinin yaşandığg, ağır yaptırımlar ve katliamlarla anılan dönemdir. Türkiye Cumhuriyeti Devleti bu dönemde de eğitim ve kültür alanında yeni kararları yürürlüğe koymayı sürdürmüştür. Matbuat Umum Müdürlüğü tarafından 11.05.1937 tarihinde yayımlanarak yazar ve kitapçılara gönderilen tamim ile kişiler göreve davet edilmişlerdir. Tamime göre, halk anlatılarının (kitaplarının) yeniden ele alınarak, irticayı teşvik edici ve batıl inançlı ögelerden ayıklanarak, yetiştirilmek istenilen yeni nesle uygun hale getirilmesi, Millî ve kültürel değerler içeren ögelerle donatılması gerekmektedir. Köroğlu, Âşık Garip, Leyla ile Mecnun, Yedi Âlimler, Tahir ile Zühre, Binbir Gece, Ferhat ile Şirin vb. halk anlatılarındaki (kitaplarındaki) tipolojinin Türk İnkılâp ve medeniyetinin amaçlarına uygun mesajlar veren olay örgüsü içerisinde yeniden kurgulanmaları gerekmektedir. Söz konusu tamim üzerine dönemin yazar ve aydınları yandaş yahut karşı1 görüşler ileri sürmüşlerdir (Elçin 1997: 61, Güvenç 2014: 50-57). 
Söz konusu tamimde pek çok halk kitabı, anlatısı ve tipolojisi belirtilmiş ise de, Dede Korkut Kitabı ve tipolojisinden doğrudan veya dolaylı söz edilmemesi dikkat çekici ve önemlidir. Dede Korkut Kitabı'nın popüler yayınları bağlamında bu dönemde (7) adet yayımın gerçekleştirildiği görülmüştür. Bir yayında yazar adının kaydedilmemesine karşın (6) adet yayında kayıtlı bulunduğu; İstanbul (5) ve Ankara'da (1), tamamının özel sektör tarafından yayımlandığı; sayfa sayısı 50-200 arasında olan bu yayınların çoğunluğunun hikâyelerden oluştuğu ve ağırlıklı olarak çocuk okur hedef kitleye hitap ettiği anlaşılmıştır. Orhan Şaik Gökyay'ın güncel dille ve genel okur kitlesine yönelik yaptığı ilk yayın bu döneme denk düşmüştür.

\subsection{6-1955 yılları arası dönem}

1946-1955 yılları arası dönem, Türkiye Cumhuriyeti Devleti ve halkı için siyasî, sosyal ve ekonomik zeminde değişim sürecinin başlangıç dönemidir. Çok partili siyasî hayata geçiş ve iktidar değişikliğinin gerçekleştiği bu dönemde toplumda liberal hayat tarzı yerleşmeye başlamıştır.

Dede Korkut Kitabı'nın popüler yayınları bağlamında bu dönemde (5) adet yayının yayımlandığı görülmüştür. Tamamının yazar adının kayıtlı olduğu yayınların İstanbul (3) ve Ankara'da (2); \% 92'lik oranda özel sektör tarafından; 100-200 sayfa sayısında; boy, hikâye ve senaryo türünde ve ağırlıkla çocuk okur hedef kitleye yönelik üretildiği anlaşılmıştır.

\subsection{6-1965 yılları arası dönem}

1956-1965 yılları arası, Türkiye'de siyasî çalkantıların, darbe ve darbe girişimlerinin öne çıktığı dönemdir.

Dede Korkut Kitabı'nın popüler yayınları bağlamında bu dönemde (15) adet yayının yayımlandığı görülmüştür. Biri dışında yazar adının kayıtlı olduğu yayınların İstanbul (12), Ankara (2) ve İzmir'de (1); iki adedi dışında özel sektör tarafından; çoğunlukla +200 sayfa sayısında; boy, hikâye ve senaryo türünde ve ağırlıkla yetişkin okur hedef kitleye yönelik üretildiği anlaşılmıştır. Dönem içerisinde, İstanbul ve Ankara dışında İzmir'de de yayıncılık girişimine katkı sağlanması, senaryo türü ürün miktarında artış, yetişkin okur hedef kitleye yönelim ve +200 sayfalı yayın miktarının çoğalması dikkati çekmiştir. Yıllar itibarıyla 1962 yılında (7) adet yayın, \% 47,5'lik oranla ilk sırayı alırken; bu oranı (3) adet yayın ile 1958 yılı takip etmektedir. Toplumdaki okuma seviyesinin ve Dede Korkut Kitabı ölçekli sanatsal formlu girişimlerin artışı ile özdeşleştirilebilecek bu gelişme, Türkiye toplumunun eğitim ve kültürel seviye yükselişinin yıllar itibarıyla artış hızını da ortaya koymuştur.

\subsection{6-1975 yılları arası dönem}

1966-1975 yılları arası, dünyada sol eğilimli ideoloji ve eylemlerinin artış gösterdiği, Türkiye'nin de bu gelişmelerden etkilendiği; ülkede ekonomik ve siyasî sorunların devam ettiği; 12 Mart 1971 tarihinde Türk Silahlı Kuvvetlerinin verdiği muhtıra sonucu hükümetin istifa ettiği ve 20 Temmuz 1974 tarihinde Kıbrıs Barış Harekâtı'nın gerçekleşmesi sonrasında Türkiye’ye karşı uluslararası ambargoların başladığ 1 dönemdir. Eğitim ve kültür alanında ise 
Millî Eğitim Bakanlığg tarafından Dede Korkut Kitabı’nın da içinde olduğu, “1000 Temel Eser"10 dizisi projesi planlanmış, yürürlüğe konulmuş ve yayımları gerçekleştirilmeye başlanılmıştır.

Dede Korkut Kitabı'nın popüler yayınları bağlamında bu dönemde (29) adet yayının yayımlandığı görülmüştür. İki adedi haricindekilerde yazar adının kayıtlı olduğu yayınların İstanbul (27) ve Ankara'da (2); yine iki adedi haricindekilerin özel sektör tarafından; çoğunlukla 0-50 sayfa sayısında; boy, hikâye ve senaryo türünde ve ağırlıkla çocuk okur hedef kitleye yönelik üretildiği anlaşılmıştır. Yıllar itibarıyla 1972 yılında (12) adet yayın, \% 40'lık oranla ilk sırayı alırken; bu oranı (5) adet yayın ile 1975 yılı takip etmektedir. Dönem içerisinde, çocuk okur hedef kitleye yönelimin ve hikâye türü yayın miktarının artışı dikkati çekmiştir. Yine bu dönem de Millî Eğitim Bakanlığının “1000 Temel Eser” dizisi projesi kapsamında Dede Korkut Kitabı'nın popüler yayını bakanlık tarafından yayımlanmasına karşın istatiksel etki oluşturmadı̆̆ı gözlemlenmiştir.

\subsection{6-1985 yılları arası dönem}

1976-1985 yılları arası, Türkiye'de siyasî terör olaylarının ve ölümlü sonuçlarının arttığı; ülkede ekonomik ve siyasi sorunların çoğalarak devam ettiği; 12 Eylül 1980 tarihinde Türk Silahlı Kuvvetlerinin darbe ile yönetime el koyduğu ve sonrasındaki seçimlerde muhafazakâr-liberal eğilimli bir partinin ülke yönetimine getirildiği dönemdir.

Dede Korkut Kitabı'nın popüler yayınları bağlamında bu dönemde (46) adet yayının yayımlandığı görülmüştür. (4) adedinde bulunmamasına karşın (41) adedinde yazar adının kayıtlı olduğu yayınların İstanbul (41), Ankara (2) ve Isparta'da (1); tamamının özel sektör tarafından; nispi çoğunluğunun 0-50 ve +200 sayfa sayısında; boy ve hikâye türünde; ağırlıkla da çocuk okur hedef kitleye yönelik yayımlandığı anlaşılmıştır.

Yıllar itibarıyla 1983 yılında (12) adet yayın, \% 26'lık oranla ilk sırayı alırken; bu oranı (9) adet yayın ile 1980 yılı takip etmiştir. Dönem içerisinde, çocuk okur hedef kitleye yönelimin ve hikâye türü yayın miktarının artışı dikkati çekmiştir. Ayrıca (1) adet senaryo çalışmasının varlığı da dikkatlerden kaçmamıştır.

\subsection{6-1995 yılları arası dönem}

1986-1995 yılları arası, Türkiye'de hükümetlerin kısa aralıklarla değiştiği; ekonomik ve sosyal sorunların yoğunlaştığı; ayrılıkçı terör örgütlerinin silahla bölücü terör faaliyetlerini arttırdığ ; toplumda kimi sosyal kimlik gruplarının siyasî, ekonomik ve sosyal birliktelikler oluşturmaya başladığı ve yapılan genel yahut yerel seçimlerdeki oy dağılımlarının önceki dönemlere göre farklılaştığı dönemdir.

Dede Korkut Kitabı'nın popüler yayınları bağlamında bu dönemde (35) adet yayının yayımlandığı görülmüştür. (6) adedinde bulunmamasına karşın (29) adedinde yazar adının kayıtlı olduğu yayınların İstanbul (23), Ankara (9), Trabzon (2) ve Sivas’ta (1); kamu "Millî Eğitim Bakanlığı” (6) ile özel sektör (29) tarafından; nispi çoğunluğunun 50-100 ve +200 sayfa sayısında; nispi çoğunluğu boy ve hikâye türünde; ağırlıkla da çocuk okur hedef kitleye yönelik yayımlandığı anlaşılmıştır. Yıllar itibarıyla 1994 yılında (9) adet yayın, \% 25'lik 
oranla ilk sırayı alırken; bu oranı (7) adet yayın ile 1992 yılı takip etmiştir. Diğer yıllarda bir-iki veya üçer yayın göze çarpmaktadır. Dönem içerisinde, çocuk okur hedef kitleye yönelimin (çocuklar için 25, yetişkinler için 10 yayın) ve hikâye türü yayın miktarının artışı dikkati çekmiştir. Ayrıca Dede Korkut Kitabı ölçekli (1) adet senaryo ve (5) adet roman çalışmasının varlığı da dikkatlerden kaçmamıştır. Kamu kurumlarının yayıncılık faaliyetine sınırlı miktarlarda olsa katkı sağlamaları; İstanbul ve Ankara dışında Sivas ve Trabzon'da da yayıncılık girişimlerinde bulunulması ve Dede Korkut ölçekli yayınlarda yazar adı kaydından sarfınazar edilmesi yönündeki nispi artış dönemin dikkate değer kültürel faaliyetleri olarak kayıtlara geçmiştir.

\subsection{6-2005 yılları arası dönem}

1996-2005 yılları arası, Türkiye'de bir önceki dönemin sosyal, siyasî, ekonomik ve terör sorunlarının ağırlaşarak devam ettiği; hükümetlerin kısa aralıklarla değiştiği; ordu içerisindeki kimi gruplarca tarihe "28 Şubat Süreci” (1997) olarak geçecek, siyasete aktif yahut pasif müdahalelerde bulunulduğu; 2002 yılından itibaren seçimle yönetime gelen hükümetin, ülkenin sosyal, ekonomik ve siyasi yapısında önemli değişiklikleri gerçekleştirmeye başladığı dönemdir. Eğitim ve kültür alanında ise, Millî Eğitim Bakanlığınca 19.08.2004 gün ve 2004/ 60 sayılı "100 Temel Eser Genelgesi” yayımlanarak içerisinde Dede Korkut Kitabı'nın da bulunduğu yüz temel eserin Türk Dili ve Edebiyatı dersi müfredatı ile ilişkilendirilmesi ve öğrencilerin okumalarının teşvik edilmesi sağlanmıştır.

Dede Korkut Kitabı'nın popüler yayınları bağlamında bu dönemde (113) adet yayının yayımlandığı görülmüştür. (10) adedinde bulunmamasına karşın (103) adedinde yazar adının kayıtlı olduğu yayınların İstanbul (93), Ankara (15), İzmir (1), Konya (1) ve Bursa'da (1); kamu (10) ile özel sektör (103) tarafindan; nispi çoğunluğunun 0-50 ve 50-100 sayfa sayısında; nispi çoğunluğu boy (33) ve hikâye (45) türünde; ağırlıkla da çocuk okur hedef kitleye yönelik yayımlandığı anlaşılmıştır. Yıllar itibarıyla 2005 yılında (30) adet yayın, \% 22'lik oranla ilk sırayı alırken; bu oranı (25) adet yayın ile 2003 yılı takip etmiştir. Diğer yıllarda (2004'te 17; 1997'de 12; 2002 'de 7 adet) dörder, beşer yayın göze çarpmıştır. Dönem içerisinde, çocuk okur hedef kitleye yönelimin (çocuklar için 71, yetişkinler için 42 yayın) ve hikâye türü yayın miktarının artışı dikkati çekmiştir. Ayrıca Dede Korkut Kitabı ölçekli (3) adet senaryo ve (4) adet roman çalışmasının varlığı da dikkatlerden kaçmamıştır. Kamu, devlet kurumlarının yayıncılık faaliyetine sınırlı miktarlarda da olsa katkı sağlamaları; İstanbul ve Ankara dışında İzmir, Konya ve Bursa'da da yayıncılık girişimlerinde bulunulması ve Dede Korkut ölçekli yayınlarda yazar adı kaydından sarfınazar edilmesi yönündeki nispi artış (\% 65) dönemin dikkate değer kültürel faaliyetleri olarak kayıtlara geçmiştir. Genel olarak bir önceki döneme göre yayın artış oranı \% 323'dür. Dönemin resmî istatistik verilerinden (TUIK, 2012: 84-88) Türkiye'de, 2001 yılında 9644 (edebiyat 2807); 2002 yılında 12497 (edebiyat 3225); 2003 y1lında 15976 (edebiyat 4123); 2004 yılında 15434 (edebiyat 4491); 2005 yılında 31050 (edebiyat 9036) adet yayın yapıldığı tespit edilmiştir. 2005 yılında gerçekleştirilen yayım miktarının bir önceki yıla göre \% 50 oranında artış gösterdiği dikkati çekmiştir. Dede Korkut Kitabı ölçekli yayınlarda da benzer bir artış görülmüştür. "100 Temel Eser" ${ }^{11}$ genelgesinin yayımlanmasını bu artışın en önemli nedeni olarak kabul etmek gerekecektir. 


\subsection{6-2015 yılları arası dönem}

2006-2015 yılları arası, Türkiye'de 2002 yılından itibaren seçimle yönetime gelen hükümetin, ülkenin sosyal, ekonomik ve siyasî yapısında önemli değişiklikleri gerçekleştirmeyi sürdürdüğü; Genelkurmay Başkanlığı internet sitesinde yayımlanan ve tarihe "27 Nisan 2007 e-muhtırası" olarak geçecek sürecin yaşandığı; terörle mücadelede farklı yöntemlerin uygulamaya geçirildiği (çözüm süreci vs.); çevre ülkelerdeki savaşların ve diğer gelişmelerin siyasî, ekonomik ve sosyal etkilerinin ülkede günlük hayatı ve uluslararası ilişkileri olumsuz yönde etkilediği dönemdir.

Dede Korkut Kitabı'nın popüler yayınları bağlamında bu dönemde (194) adet yayının yayımlandığı görülmüştür. (17) adedinde bulunmamasına karşın (185) adedinde yazar adının kayıtlı olduğu yayınların İstanbul (156), Ankara (26), Eskişehir (3), Konya (3), İzmir (2), Sakarya (1), Samsun (1) ve Sivas'ta (1); kamu (10) ile özel sektör (184) tarafından; nispi çoğunluğunun 0-50 ve 100-200 sayfa sayısında; nispi çoğunluğu boy (52) ve hikâye (123) türünde; ağırlıkla da çocuk okur hedef kitleye yönelik yayımlandığı anlaşılmıştır. Yıllar itibarıyla 2013 yılında (40) adet yayın, \% 21'lik oranla ilk sırayı alırken; bu oranı (30) adet yayın ile 2011 yılı takip etmiştir. Diğer yıllarda da (2006'da 20; 2007'de 21; 2008'de 9; 2009'da 13; 2010'da 19; 2012'de 15 ; 2014 'te 16 ve 2015 'te 11 adet) birbirlerine yaklaşık miktarlarda yayın göze çarpmıştır. Dönem içerisinde, çocuk okur hedef kitleye yönelimin (çocuklar için 118, yetişkinler için 77 yayın) ve hikâye türü yayın miktarının artışı dikkati çekmiştir. Ayrıca Dede Korkut Kitabı ölçekli (5) adet senaryo ve (16) adet roman çalışmasının varlığı da dikkatlerden kaçmamıştır. Kamu, devlet kurumlarının yayıncılık faaliyetine sınırlı miktarlarda olsa katkı sağlamaları; İstanbul ve Ankara dışında İzmir, Konya, Sivas, Samsun ve Sakarya'da da yayıncılık girişimlerinde bulunulması ve Dede Korkut ölçekli yayınlarda yazar adı kaydından sarfınazar edilmesi yönündeki nispi artış (\% 70) dönemin dikkate değer kültürel faaliyetleri olarak kayıtlara geçmiştir. Genel olarak bir önceki döneme göre yayınlarda \% 73 artış olmuştur.

\section{Sonuç}

Dede Korkut Kitabı Türk kültürel belleğinin sembol eserlerindendir. Türkiye'de Kilisli Muallim Rifat [Bilge], Orhan Şaik Gökyay ve Muharrem Ergin'in Dede Korkut kitapları zemininde, 1916-2015 yılları arasında pek çok "popüler yayın” yapılmıştır. Bilimsel olmayan, genel okuyucu kitlesine hitap eden ve yazılı iletişim sistematiğinde gerçekleştirilen Türkiye'deki Dede Korkut Kitabı odaklı yayınlarda yazar-yayın-okurdan oluşan üçlü yapı söz konusudur. Sözlü kültürden, yazılı kültüre geçişle anlatıcının “yazar”a; sözün metne ve dinleyicinin de "okur”a dönüştüğü bu yapı; Dede Korkut Kitabı popüler yayınlarının oluşturulmasında nicelik ve nitelik bağlamında belirleyicidir.

Örneklemler üzerinde yapılan bu çalışmada öncelikle yazarların veya yayıncıların boyları kültür aktarımının yanı sıra farklı sebep ve saiklarla yayımlandığı anlaşılan yayınlarda ağırlıklı okur hedef kitlenin çocuklar (\% 60) olduğu görülmüştür. Diğer yandan kimi yazarlar tarafından yayına adının kaydedilmemesi veya müstear ad kullanılması söz konusudur ki -1996 yılından başlayarak \% 65'e varan artış-, bu yaklaşımı "sahiplenmeme isteği”nin dışa vurumu şeklinde kıymetlendirilebilir. Sahiplenmeme isteğini oluşturan sebeplerin ise sosyal (alan hâkimiyetini koruma, tepkilerden korunma, kaçınma gibi), ekonomik (sosyo- 
psikolojik temelli ticari kaygılar gibi) ve hukuki (ceza/mobbing türü yaptırımlardan kaçma, kurtulma gibi) olabileceği kanaatine varılmıştır. Bunlarla birlikte, 1916 yılından başlayarak yayınlar nicelik bağlamında gözlemlendiğinde yayın miktarlarının kademeli olarak arttığı; 1926-1935 yılları arası dönemdeki yayın miktarlarındaki artışının bir sonraki dönemde düştüğü; 1966-1975 yılları arası dönemde yayın miktarının önceki dönemlerin iki katına çıktığ1; 1996-2005 yılları arası ve sonrası dönemde de yayın miktarının geçmiş dönemlere oranlara pek çok arttığı; son iki dönemdeki yayın miktarının diğer yılların toplam yayın miktarını da aşarak toplam yayın miktarının dörtte üçüne ulaştığı anlaşılmıştır. İstanbul ve Ankara dışındaki şehirlerde de Dede Korkut Kitabı'nın popüler yayınlarının yayımlanması ise, bu şehirlerdeki girişimci ve yayıncı potansiyelinin varlığına işaret etmiştir. Kamu, devlet kurum ve kuruluşlarının yayım gerçekleştirme oranının düşük olmasını da genel bütçeden aldıkları payla doğru orantılıdır. Yayınların sayfa sayılarının belirlenmesinde sayfa düzeni, okur hedef kitlenin beklentisi veya yazarın tercihleri, yayıncının ticari kaygılar vb. pek çok neden etkili olmaktadir.

İdarenin 1937, 1966 ve 2004 yıllarında kültür ve yayın alanına yönelik müdahale ve katkılarında Dede Korkut Kitabı'nın popüler yayınları üzerine etkisi/etkisizliği söz konusudur. Matbuat Umum Müdürlüğünün 11.05.1937 tarihli genelgesiyle halk anlatılarının (kitaplarının) yeniden ele alınması; irticayı teşvik edici ve batıl inançlı ögelerden ayıklanarak, yetiştirilmek istenilen yeni nesle uygun hale getirilmesi; Millî ve kültürel değerler içeren ögelerle donatılması gerektiği kaydedilerek pek çok halk kitabı, anlatısı ve tipolojisi belirtilmişse de, Dede Korkut Kitabı ve tipolojisinden doğrudan veya dolaylı söz edilmemiştir. 1966 yılında Millî Eğitim Bakanlığının “1000 Temel Eser” dizisi projesi kapsamında popüler Dede Korkut Kitabı bakanlık tarafından yayımlanmasına karşın istatiksel bir etki oluşturmamıştır. Millî Eğitim Bakanlığı tarafından 19.08.2004 tarihinde “100 Temel Eser Genelgesi” yayımlanarak, içerisinde Dede Korkut Kitabı'nın da bulunduğu yüz temel eserin Türk Dili ve Edebiyatı ders müfredatıyla ilişkilendirilmesi ve öğrencilerin okumalarının teşvik edilmesi istenmiştir. Dede Korkut Kitabı popüler yayınlarında 2005 yılından itibaren gerçekleştirilen \%50'den fazla artışla, genelgenin yayımı arasında organik bir bă̆ kurmak mümkündür.

Ayrıca söz konusu yayınlarda yetişkin okur hedef kitleden ziyade çocuk okur hedef kitleye odaklanıldığını ve ağırlıkla 100-200 sayfa aralığında yayınlar hazırlandığı görülmüştür.

Bilindiği üzere UNESCO Somut Olmayan Kültürel Miras Hükûmetler Arası Komitesi’nin 28 Kasım 2018 günü gerçekleştirdiği 13. oturumunda "Dede Korkut Mirası: Destan Kültürü, Halk Masalları ve Müzik”, Türkiye, Azerbaycan ve Kazakistan'ın ortak çok uluslu dosyası olarak kabul edilerek UNESCO İnsanlığın Somut Olmayan Kültürel Mirası Temsili Listesi'ne kaydedilmiştir. Dede Korkut Kitabı'nın dünya miras listesine dâhil edildiği bu dönemde Millî Eğitim Bakanlığı ile diğer yaygın ve örgün eğitim-öğretim kurumlarında Dede Korkut Kitabı'nın canlandırılmasına yönelik faaliyetler yapılmalı, genç nüfusun eğitim-öğretim çağında mutlaka Dede Korkut Kitabı ile tanışmaları; onu algılamaları, anlamaları ve değerlendirmeleri sağlanmalıdır. "Dede Korkut Mirası”, öğrencilerin millî ve manevî değerleri benimseyip hayat tarzına dönüştürmüş, üretken ve aktif vatandaşlar olarak yurdumuzun iktisadî, sosyal ve kültürel kalkınmasına katkıda bulunan bireyler şeklinde yetişebilmelerinde, konjonktürel sorunların çözümü ve geleceğin inşasında güvenle faydalanılabilecek Türk Kültürü ürünüdür. 


\section{Notlar}

1 Kilisli Muallim Rifat'ın [Bilge] yayımı metin neşri olup bilimsel inceleme ihtiva etmediği için popüler formlu ilk yayın olarak düşünülebilir.

2 Örnekleme ve örnekleme dağılımları; tamsayım ve örnekleme kavramlarını ayırt etmek, örnekleme planı hazırlamak, bir örnek araştırma için örnekleme uygulaması yapmak ve istenen bilgileri üretmek şeklinde gerçekleştirilebilir. Bu istatistikler ve bu istatistiklerle ilgili dağılımın özellikleri kullanılarak bu istatistiklerin bilgi ürettiği parametrelerden; evren aritmetik ortalaması $(\mu)$ ve evren oranı $(\pi)$ için gerekli çıkarım bilgileri üretilebilir (Özmen vd, 2012: 3-38).

3 Ölçme Düzeyleri (Ölçekler): Anakütle veya örneklemdeki istatistik birimlerin, ilgilenilen sayısal veya sözel özelliklerinin aldığı değerlerin, sayılar veya simgelerle gösterimine ölçme; ölçme sonucu değişkenin aldığı değere de ölçüm denir. Değişkenlere ilişkin ölçümler, değişkenin yapısına göre dört farklı ölçme düzeyinde (sınıflayıcı, sınırlayıcı, aralıklı ve oransal) yapılır (Aslanargun vd, 2012: 6-7).

4 Bu çalışmada popüler yayın kavramı ile Dede Korkut boylarının, üzerinde bilimsel inceleme ve analiz yapılmadan kitap halinde genel okuyucu kitlesine sunulan metin neşri kastedilmiştir.

5 Walter J. Ong (1995), sözlü kültürde görkemli bir dil ve bilgeliğin önde olmasına karşın yazılı kültürde cümlenin ifade edebileceği bütün anlamların önceden değerlendirilmesi gerektiğini, yazının sondan başa gelerek yanlışlarının düzeltilebileceğini, sözün ise "yamama" metodu ile yanlışlarının yine dille örtbas edilebileceğini (s. 125) kaydederek matbaanın metinde bulunan şeyin son şeklini aldığı ve tamamlandığı yolundaki duygunun "kapanıklık” olduğunu kaydetmiştir (s. 156-160). Bu bilgiden hareketle sözlü kültür ortamında oluşan ve icra sırasında anlatıcı-dinleyici-icra ortamı bağlamında "yamama"lara maruz kalabilen Dede Korkut boyları yazılı ortama aktarılmalarıyla yazının kapanıklığı özelliğini edinmişlerdir.

6 Liste: İlgilenilen değişkenin almış olduğu değerler, diğer bir değişkene göre veya rastgele sıralanmış ise bu tabloya verilen ad. Geniş bilgi için bkz. (Aslanurgun vd, 2012: 8-15).

7 Gizli alıntı: Bir metne ait herhangi bir parçanın ayraçlar veya italik yazıyla vurgulanmadan ve yazarı belirtilmeden alıntılanmasıdır (Aktulum 2011: 423, 2014: 83).

8 Okur bir izden, dilbilimsel bir ögeden/aykırılıktan hareketle metnin yüzey/ derin yapısını çözebilen; metinlerarası ilişki kurabilen kişidir. Ancak bu donanım gerektiren bir pratiktir. Bilim insanları, sonsuz bir kültür birikimi gerektiren metinlerarası çözümleme yapılabilmesi için iki tür okurdan söz etmektedirler. İlk okur türü, metinlerarası izin varlığından haberdar olsa bile alt (dip) bilginin kaynağını tespit edebilmesi imkânsız olan sıradan okurlardır. İkinci okur türü ise, Eizeweing’in ifadesiyle "bilgin”, "dahi”, sonsuz bir kültürel birikime sahip okurlardır (Aktulum, 2014: 56). Metnin “edebi kategorisi”nin tespitinde de ikinci okur türüne yakın okur tipolojisine ihtiyaç olduğu anlaşılmaktadır.

9 Mustafa Rahmi tarafından 1927 yılında Osmanlı Türkçesiyle yayımlanan Korkut Ata'nın Kitabı: Evvel Zaman$d a$ kitabı yayım tarihinden bir yıl sonra "Yeni Türk Harflerinin Kabulü ve Tatbiki Hakkındaki Kanun"un yürürlüğe girmesi nedeniyle okuyucuya ulaşamadığı ve zamanla unutulduğu değerlendirilerek Turan M. Türkmenoğlu tarafından 2014 yılında Türkiye Türkçesi'ne aktarılarak Korkut Ata'nın Kitabı başlığı ile yayımlanmıştır (Türkmenoğlu, 2014).

10 Millı̂ Eğitim Bakanlığınca 1966 yılında “1000 Temel Eser” projesiyle seri kitap yayımlama kararı alınmış ve 1968-1972 İkinci Beş Yıllık Kalkınma Plânı’na konulmuştur. Dizinin ilk kitabı olarak Muharrem Ergin'in Dede Korkut Kitabı 1969 yılında Millı̂ Eğitim Bakanlığınca yayımlanmıştır. Bkz. (Özbalcı, 2011: 126-138)

11 Genelgenin 17.12.2018 tarihinde yürürlükten kaldırılması, Dede Korkut Kitabı'nın popüler kitapların yayımına yönelik ne tür etkiler yapacağı zaman içerisinde görülecektir. 


\section{Kaynaklar}

Aktulum, K. (2011). Metinlerarasılık / Göstergelerarasılık, İstanbul: Kanguru.

Aktulum, K. 2014) Metinlerarası ilişkiler. Ankara: Kanguru.

Akyüz, E. (2012). Çocuk hukuku -Çocukların hakları ve korunmast-. (2. bs.) Ankara: Pegem.

Arıkan, Z. (1999). Halkevlerinin kuruluşu ve tarihsel işlevi. Ankara Üniversitesi Türk Inkılâp Enstitüsü Atatürk Yolu Dergisi. (6. Cilt), S. 23, ss. 261-281.

Aslanargun, A. vd. (2012). İstatistik-I. Eskişehir: Anadolu Üniversitesi.

Bekki, S. (2014). Dedem Korkut Kitabı bibliyografyası üzerine bir deneme. Ankara: Berikan,

Binbaşığlu, C. (2005). Türk eğitim düşüncesi tarihi. Ankara: Anı.

Çobanoğlu, Ö.( 2012). Halkbilimi kuramları ve araştırma yöntemleri tarihine giriş. (6. bs.). Ankara: Akçă̆.

Elçin, Ş. (1997). Halk romanları ile ilgili bir tamim ve iki mektup. Halk Edebiyatı Araştırmaları II. (3. bs.). Ankara: Akçağ.

Ergin, M. (1953). Dede Korkut. İstanbul: İstanbul Üniversitesi Türkiyat Enstitüsü. Doktora Tezi, No: 401.

Ergin, M. (1961) Dede Korkut'un grameri. İstanbul: İstanbul Üniversitesi Edebiyat Fakültesi. Doçentlik Tezi.

Ergin, M. (1963). Dede Korkut Kitabı-II /Indeks-Gramer. Ankara: Türk Dil Kurumu.

Ergin, M. (1989). Dede Korkut kitabl-1. Ankara: TTK.

Göktürk, A. (2010). Okuma uğraşı -Yazın metninin kavranışında okur metin-yazar-. (6. bs.). İstanbul: Yap1 Kredi.

Gökyay, O. Ş. (1938). Dede Korkut. İstanbul: Arkadaş.

Günay, D.. (2007). Metin bilgisi. İstanbul: Multilingua.

Güvenç, A. Ö. (2014). Halk anlatılarının yeniden yazım sürecinde Basat'ın Tepegöz'ü öldürmesi hikâyesi (1923-2003). İstanbul: Gece Kitaplı̆̆1.

Karabekir, K. (2008). İstiklal harbimiz. (2.cilt). İstanbul: Yap1 Kredi.

Ong, W. J. (1995). Sözlü ve yazılı kültür -Sözün teknolojileşmesi-. İstanbul: Metis.

Özbalcı, M. (2011): Yarım kalmış bir proje: 1000 temel eser dizisi, Türk Yurdu, S. 286, Haziran, ss. 126-138.

Özmen, A. vd. (2012). İstatistik-II. Eskişehir: Anadolu Üniversitesi.

Şenöz-Ayata, C. (2005). Metindilbilim ve Türkçe. İstanbul: Multilingual.

Türkmenoğlu, M. T.. (2014). Korkut Ata'nın kitabı. İstanbul: Milenyum.

Veren, E. (2018). Türkiye'de popüler yayınlarda Dede Korkut Kitabı. İstanbul: Doğu Kütüphanesi.

Ziya G. (1917a). Dede Korkut masallarından: Deli Dumrul. Yeni Mecmua 1/4, 2 Ağustos, ss.73.

Ziya G. (1917b). Dede Korkut masallarından: Tepegöz. Yeni Местиа 1/5, 9 Ağustos, ss.93-97.

Ziya G. (1917c). Dede Korkut masallarından: Boğa ile Boğaç. Yeni Mecmua 1/7, 23 Ağustos, ss.127128.

Ziya G. (1923). Altun Işılk. İstanbul: Türkiye Cumhuriyeti Maarif Vekâleti Neşriyatı, Matbaa-i Âmire.

Ziya G. (1977). Dede Korkut masalları: Tepegöz. (B. Taştan ve S.Sönmez, Haz.). İstanbul: Kalem. 